\title{
ANALISIS KEPUASAN PASIEN DI INSTALASI RAWAT INAP RUMAH SAKIT UMUM (RSU) HAJI SURABAYA BERDASARKAN DIMENSI MUTU DABHOLKAR
}

\section{THE ANALYSIS OF PATIENT SATISFACTION IN INPATIENT INSTALLATION OF SURABAYA HAJJ HOSPITAL BASED ON THE DABHOLKAR DIMENSION}

\author{
Kidhung Piranti \\ Departemen Administrasi dan Kebijakan Kesehatan \\ Fakultas Kesehatan Masyarakat Universitas Airlangga, Surabaya, Indonesia \\ Alamat Korespondensi: Kidhung Piranti \\ E-mail: Kidhung22@gmail.com
}

\begin{abstract}
Community Satisfaction Index (CSI) in Inpatient Installation of Surabaya Hajj Hospital increased during $2012-$ 2016, but it has not reached the standard determined by the hospital, that is $85 \%$. This study aims to analyze the patient satisfaction in the Inpatient Installation of Surabaya Hajj Hospital based on Dabholkar Dimension. This study is descriptive observational analysis by using cross-sectional approach with systematic random sampling technique. The samples obtained were 142 respondents. This research analyzes patient satisfaction in the Inpatient Installation by categorizing patient satisfaction in each element based on Dabholkar Dimension. The element with a composite mean $\geq$ the aggregate of composite average means satisfied and not becoming an issue, while the element with composite mean < the aggregate of composite average means unsatisfied and becomming an issue. Quality service issue can be a problem hence it needs to be resolved as soon as possible. The results of this study can be used to prepare the recommendation of health service improvement to increase patient satisfaction.
\end{abstract}

Keywords: Dabholkar dimension, quality issue, patient satisfaction.

\begin{abstract}
ABSTRAK
Indeks Kepuasan Masyarakat (IKM) di Instalasi Rawat Inap RSU Haji Surabaya dari tahun 2012 hingga 2016 mengalami peningkatan namun belum mencapai standar yang ditetapkan rumah sakit yaitu sebesar $85 \%$. Tujuan dari penelitian ini adalah menganalisis kepuasan pasien di Instalasi Rawat Inap RSU Haji Surabaya berdasarkan Dimensi Mutu Dabholkar. Penelitian ini bersifat observasional deskriptif menggunakan pendekatan cross sectional dengan teknik pengambilan sampel systematic random sampling. Diperoleh sampel sebanyak 142 responden. Penelitian ini menganalisis kepuasan pasien di Instalasi Rawat Inap dengan melakukan pengkatagorian kepuasan pasien di tiap unsur berdasarkan Dimensi Mutu Dabholkar. Unsur dengan mean komposit $\geq$ rata-rata komposit keseluruhan berarti puas dan bukan isu, sedangkan unsur dengan mean komposit < rata-rata komposit keseluruhan berarti tidak puas dan menjadi isu. Isu mutu layanan dapat menjadi masalah sehingga harus segera diselesaikan. Hasil analisis digunakan untuk menyusun rekomendasi perbaikan mutu pelayanan kesehatan sehingga dapat meningkatkan kepuasan pasien.
\end{abstract}

Kata kunci: dabholkar, isu mutu, kepuasan pasien

\section{PENDAHULUAN}

Rumah sakit merupakan sarana kesehatan yang memberikan pelayanan kesehatan kepada masyarakat dan memiliki peran yang sangat strategis dalam mempercepat peningkatan derajat kesehatan masyarakat. Rumah sakit dituntut memberikan pelayanan yang bermutu sesuai dengan standar yang ditetapkan dan dapat menjangkau seluruh lapisan masyarakat. Rumah sakit memberikan pelayanan kesehatan yang menyelenggarakan pelayanan kesehatan perorangan secara paripurna dengan menyediakan pelayanan rawat inap, rawat jalan, dan gawat darurat (Permenkes No 340, 2010). Dewasa ini makin banyak jumlah rumah sakit yang berdiri sehingga memunculkan persaingan ketat antar rumah sakit sekaligus menjadikan tantangan bagi pengelola maupun pemilik 
rumah sakit untuk memperbaiki kualitas pelayanan yang dipercaya oleh masyarakat

RSU Haji Surabaya adalah salah satu rumah sakit di Kota Surabaya dengan tipe B. RSU Haji Surabaya berperan meningkatkan pelayanan kesehatan sesuai dengan tugas pokok dan fungsinya. Standar Pelayanan Minimal (SPM) merupakan ketentuan jenis dan mutu pelayanan dasar urusan wajib daerah yang berhak diperoleh setiap warga secara minimal dan merupakan tolak ukur pelayanan minimum yang diberikan Badan Layanan Umum (BLU) kepada masyarakat. Berdasarkan hasil evaluasi capaian indikator SPM di RSU Haji Surabaya yang belum memenuhi standar sebanyak 31 SPM, dan salah satu indikatornya adalah Indeks Kepuasan Masyarakat (IKM). IKM merupakan tingkat kepuasan masyarakat yang dilakukan melalui survey terhadap pelayanan yang diterima dari penyelenggara pelayanan (Laporan Kinerja RSU Haji Surabaya Tahun ,2015).

Berdasarkan data sekunder yang diperoleh, bahwa hasil survei Indeks Kepuasan Masyarakat (IKM) dari tahun 2012 hingga 2016 mengalami peningkatan namun belum mencapai standar yang ditetapkan rumah sakit yaitu sebesar $85 \%$. Terdapat sembilan unsur IKM yang dinilai di Instalasi Rawat Inap RSU Haji Surabaya dan dapat dikelompokkan ke dalam Dimensi Mutu Dabholkar, yaitu Physical aspect (produk spesifik), Reliability (waktu pelayanan dan maklumat pelayanan), Personal Interaction (perilaku pelaksana), Problem Solving (kompetensi pelaksana dan penanganan pengaduan), serta Policy (persyaratan, prosedur, dan biaya/tarif) (Laporan Kinerja BLUD RSU Haji Surabaya Tahun 2016: Laporan Akhir IKM RSU Haji Surabaya).

IKM merupakan salah satu tolak ukur penilaian kepuasan pasien terhadap pelayanan kesehatan yang diberikan sehingga perlu dilakukan penelitian yang bertujuan untuk menganalisis kepuasan pasien di Instalasi Rawat Inap RSU Haji
Surabaya berdasarkan Dimensi Mutu Dabholkar. Penelitian ini diharapkan dapat memberikan rekomendasi untuk perbaikan mutu pelayanan di Instalasi Rawat Inap RSU Haji Surabaya.

\section{METODE PENELITIAN}

Penelitian ini merupakan penelitian observasional karena peneliti tidak memberikan perlakuan terhadap subyek penelitian. Penelitian ini menggunakan desain penelitian cross sectional karena penelitian ini dilakukan pada satu waktu tertentu. Populasi penelitian adalah seluruh pasien yang terdaftar di Instalasi Rawat Inap RSU Haji Surabaya pada saat dilakukan penelitian. Data yang digunakan adalah rata-rata jumlah pasien masuk pada tahun 2016. Berdasarkan data pada tahun 2016 terdapat 13.896 pasien masuk di Instalasi Rawat Inap. Penentuan besar populasi didasarkan pada data tersebut sehingga dalam satu bulan rata-rata pasien masuk sebanyak 1.158 pasien. Penentuan sampel dilakukan menggunakan teknik systematic random sampling dengan asumsi bahwa populasi dalam penelitian ini homogen dan tersebar di lokasi yang sama. Besar sampel yang akan diteliti dihitung menggunakan rumus sehingga diperoleh 142 responden.

Penelitian dilakukan di Instalasi Rawat Inap RSU Haji Surabaya pada bulan Juni sampai Juli 2017. Variabel dalam penelitian ini yaitu kepuasan pasien pada mutu layanan berdasarkan Dimensi Mutu Dabholkar yaitu dimensi fisik, reliabilitas, interaksi personal, pemecahan masalah, dan kebijakan. Angka yang digunakan pada jawaban kepuasan responden menggunakan skala likert yaitu tidak puas: 1, kurang puas: 2, biasa saja/netral: 3, puas: 4 , sangat puas: 5. Pengumpulan data primer dilakukan dengan wawancara kepada responden menggunakan kuesioner yang dikembangkan dari teori kualitas jasa berdasarkan Dimensi Mutu Dabholkar, sedangkan data sekunder diperoleh dari Laporan Kinerja Pemerintah (LKJ IP) 
tahun 2016 dan laporan tentang profil RSU Haji Surabaya.

Sebelum instrumen berupa kuesioner disebarkan, dilakukan uji validitas dan reliabilitas. Uji validitas dan reliabilitas dilakukan dengan membagikan kuesioner kepada 30 responden yaitu pasien di Instalasi Rawat Inap RSU Haji Surabaya kemudian diolah menggunakan program SPSS.

Sebelum analisis data, dilakukan perhitungan kategori nilai baru (komposit) sebagai rating nilai komposit baru untuk menentukan kategori kepuasan pasien dengan cara (Supranto 2001):

$$
\frac{\text { nilai max }- \text { nilaimin }}{\text { kategoriyangdiinginkan }}=\frac{5-1}{5}=0,8
$$

Sehingga diperoleh kategori nilai baru komposit kepuasan sebagai berikut:

$$
\begin{array}{ll}
1-1,8 & =\text { tidak puas } \\
1,81-2,6 & =\text { kurang puas } \\
2,61-3,4 & =\text { biasa saja/netral } \\
3,41-4,2 & =\text { puas } \\
>4,2 & =\text { sangat puas }
\end{array}
$$

Teknik analisis data dalam penelitian ini menggunakan program Microsoft Excel. Teknik analisis data dimulai dengan menghitung total skor kepuasan yaitu memberikan skor atas jawaban responden pada setiap unsur dengan cara:

$$
\sum X i=\left(n_{1} \times 1\right)+\left(n_{2} \times 2\right)+\left(n_{3} \times 3\right)+\left(n_{4} \times 4\right)+\left(n_{5} \times 5\right)
$$

Keterangan:

$$
\begin{array}{ll}
\sum \mathrm{Xi} & =\text { total skor kepuasan } \\
\mathrm{n}_{1} & =\text { frekuensi kepuasan } 1 \\
\mathrm{n}_{2} & =\text { frekuensi kepuasan } 2 \\
\mathrm{n}_{3} & =\text { frekuensi kepuasan } 3 \\
\mathrm{n}_{4} & =\text { frekuensi kepuasan } 4 \\
\mathrm{n}_{5} & =\text { frekuensi kepuasan } 5
\end{array}
$$

Tahap analisis data selanjutnya yaitu menghitung mean komposit masingmasing unsur pertanyaan kepuasan dengan cara:

$$
\text { Mean Komposit }=\sum X i / N
$$

Keterangan:

$\begin{array}{ll}\sum \mathrm{Xi} & =\text { total skor kepuasan } \\ \mathrm{N} & =\text { jumlah responden }\end{array}$

Hasil dari mean komposit masingmasing unsur digunakan untuk menghitung nilai rata-rata komposit keseluruhan dengan cara:

Rata-rata komposit keseluruhan $=$ mean komposit / K

Keterangan:

$\mathrm{K}$ = banyaknya unsur

Analisis data dilanjutkan dengan menggunakan nilai mean komposit dan nilai rata-rata komposit keseluruhan sebagai acuan. Unsur dengan mean komposit $\geq$ rata-rata komposit keseluruhan berarti pasien puas dan bukan isu, sedangkan unsur dengan mean komposit kurang dari rata-rata komposit keseluruhan berarti pasien tidak puas dan menjadi isu. Isu yang telah ditemukan selanjutnya digunakan untuk menyusun rekomendasi sebagai perbaikan mutu pelayanan. Penelitian ini telah memperoleh keterangan lolos kaji etik dari Komisi Etik FKM No : 307-KEPK.

\section{HASIL}

\section{Dimensi Fisik}

Menurut Dabholkar (1996) dimensi fisik meliputi penampilan fisik dan kenyamanan yang ditawarkan kepada pelanggan berkaitan dengan layout fasilitas fisik. Keteraturan tatanan interior dan eksterior ruangan rawat inap yang menarik secara visual, perlengkapan medis dan non medis yang tertata rapi, kebersihan dan kenyamanan ruangan, serta kemudahan pelanggan dalam mencari ruangan.

Berdasarkan Tabel 1. dapat diketahui bahwa terdapat lima unsur termasuk kategori puas dan satu unsur termasuk kategori biasa saja/netral. Sebagian besar pasien merasa puas 
terhadap pelayanan yang diberikan namun masih terdapat unsur dengan nilai mean komposit di bawah nilai rata-rata komposit keseluruhan sehingga dapat menjadi isu. Isu dalam unsur-unsur dimensi fisik yaitu penataan layout interior dan eksterior, kebersihan ruang tunggu dan kamar kecil, serta kenyamanan ruangan (penerangan, kesejukan, dan ketenangan).

\section{Dimensi Reliabilitas}

Dimensi reliabilitas berkaitan dengan pelayanan yang diberikan sejak awal tanpa membuat kesalahan dan sesuai dengan waktu yang telah disepakati. Reliabilitas dibagi menjadi dua sub dimensi yaitu keeping promise (memenuhi janji) dan doing it right (memberikan layanan dengan tepat).

Berdasarkan Tabel 2. dapat diketahui bahwa semua unsur termasuk dalam kategori puas. Meskipun kategori puas, namun terdapat beberapa unsur dengan nilai mean komposit di bawah nilai rata-rata komposit keseluruhan sehingga dapat menjadi isu. Isu dalam unsur-unsur dimensi reliabilitas, yaitu kecepatan dan ketepatan pelayanan yang diberikan sejak awal serta ketepatan waktu pemeriksaan laboratorium.

\section{Dimensi Interaksi Personal}

Dimensi interaksi personal berkaitan dengan pemberi layanan dalam menumbuhkan kepercayaan pasien dengan sikap sopan dan senantiasa membantu. Dimensi ini mencerminkan para petugas memperlakukan pasien dengan pengetahuan yang memadai dalam menjawab pertanyaan dari pasien serta memberikan perhatian yang tulus sehingga pasien merasa aman dan nyaman dalam memanfaatkan pelayanan di rumah sakit.

Tabel 1. Kepuasan Pasien terhadap Unsur Dimensi Fisik Instalasi Rawat Inap RSU Haji Surabaya Tahun 2017

\begin{tabular}{lrll}
\hline \multicolumn{1}{c}{ Unsur } & Mean Komposit & Kategori & \multicolumn{1}{c}{ Ket.Isu } \\
\hline Kelengkapan peralatan medis & 3,85 & Puas & Bukan Isu \\
\hline Penataan layout interior dan eksterior & 3,49 & Puas & Isu \\
\hline $\begin{array}{l}\text { Kerapian penempatan plastik tempat obat dan } \\
\text { penampilan dokter }\end{array}$ & 3,66 & Puas & Bukan Isu \\
\hline Kebersihan ruang tunggu dan kamar kecil & 3,55 & Puas & Isu \\
\hline Ketersediaan penunjuk nama ruang & 3,91 & Puas & Bukan Isu \\
\hline $\begin{array}{l}\text { Kenyamanan ruangan (penerangan, kesejukan, } \\
\text { dan ketenangan) }\end{array}$ & 3,32 & $\begin{array}{l}\text { Biasa } \\
\text { saja/netral }\end{array}$ & Isu \\
\hline Nilai Rata-Rata Komposit Keseluruhan & 3,63 & & \\
\hline
\end{tabular}

Tabel 2. Kepuasan Pasien terhadap Unsur Dimensi Reliabilitas di Instalasi Rawat Inap RSU Haji Surabaya Tahun 2017

\begin{tabular}{lrrr}
\hline \multicolumn{1}{c}{ Unsur } & Mean Komposit & Kategori & Ket.Isu \\
\hline Ketepatan visite dokter & 3,82 & Puas & Bukan Isu \\
\hline Ketepatan jam makan pasien & 4,13 & Puas & Bukan Isu \\
\hline $\begin{array}{l}\text { Kecepatan dan ketepatan pelayanan yang } \\
\text { diberikan sejak awal }\end{array}$ & 3,73 & Puas & Isu \\
\hline $\begin{array}{l}\text { Kemudahan mendapatkan obat yang } \\
\text { dibutuhkan pasien }\end{array}$ & 3,96 & Puas & Bukan Isu \\
\hline $\begin{array}{l}\text { Ketepatan waktu pemeriksaan } \\
\text { laboratorium }\end{array}$ & 3,45 & Puas & Isu \\
\hline Nilai Rata-Rata Komposit Keseluruhan & & & \\
\hline
\end{tabular}


Berdasarkan Tabel 3. dapat diketahui bahwa terdapat 6 unsur termasuk dalam kategori puas dan 3 unsur termasuk dalam kategori biasa saja/netral. Unsur dengan kategori biasa saja/netral memiliki nilai mean komposit di bawah nilai ratarata komposit keseluruhan sehingga dapat menjadi isuIsu dalam unsur-unsur dimensi interaksi personal yaitu empati perawat terhadap keluhan pasien, keramahan perawat dalam memenuhi permintaan pasien, serta respek perawat dalam memperhatikan pasien.

\section{Dimensi Pemecahan Masalah}

Dimensi pemecahan masalah berkaitan dengan kepekaan pemberi layanan terhadap keluhan dari pasien dan keluarga pasien. Termasuk kemampuan pemberi layanan dalam memecahkan masalah pasien dengan tulus dan jujur sehingga dapat mencegah ketidakpuasan. Dimensi ini melibatkan interaksi langsung antara petugas dengan pasien secara spesifik dalam penanganan masalah. Pemecahan masalah juga mencakup keberadaan petugas kesehatan.

Tabel 3. Kepuasan Pasien terhadap Unsur Dimensi Interaksi Personal di Instalasi Rawat Inap RSU Haji Surabaya Tahun 2017

\begin{tabular}{lrll}
\hline \multicolumn{1}{c}{ Unsur } & Mean Komposit & Kategori & Ket.Isu \\
\hline $\begin{array}{l}\text { Dokter dan perawat memiliki pengetahuan } \\
\text { yang memadai dalam menjawab pertanyaan } \\
\text { pasien }\end{array}$ & 4,04 & Puas & Bukan Isu \\
\hline $\begin{array}{l}\text { Sikap dokter dapat menumbuhkan } \\
\text { kepercayaan pasien }\end{array}$ & 4,17 & Puas & Bukan Isu \\
\hline $\begin{array}{l}\text { Empati perawat terhadap keluhan pasien } \\
\text { Responsif perawat dalam memberikan }\end{array}$ & 3,40 & $\begin{array}{l}\text { Biasa } \\
\text { saja/netral }\end{array}$ & Isu \\
\hline $\begin{array}{l}\text { Delayanan } \\
\text { lebih lannjut diberikan }\end{array}$ & 3,72 & Puas & Bukan Isu \\
\hline $\begin{array}{l}\text { Keramahan perawat dalam memenuhi } \\
\text { permintaan pasien }\end{array}$ & 3,73 & Puas & Bukan Isu \\
\hline $\begin{array}{l}\text { Perhatian dokter dan perawat kepada pasien } \\
\begin{array}{l}\text { Respek perawat dalam memperhatikan } \\
\text { pasien }\end{array}\end{array}$ & 3,26 & $\begin{array}{l}\text { Biasa } \\
\text { saja/netral }\end{array}$ & Isu \\
\hline $\begin{array}{l}\text { Kesopanan dokter dan perawat menerima } \\
\text { konsultasi via telepon }\end{array}$ & 3,88 & Puas & Bukan Isu \\
\hline Nilai Rata-Rata Komposit Keseluruhan & 3,34 & $\begin{array}{l}\text { Biasa } \\
\text { saja/netral }\end{array}$ & Isu \\
\hline
\end{tabular}

Tabel 4. Kepuasan Pasien terhadap Unsur Dimensi Pemecahan Masalah di Instalasi Rawat Inap RSU Haji Surabaya Tahun 2017

\begin{tabular}{lclc}
\hline \multicolumn{1}{c}{ Unsur } & Mean Komposit & \multicolumn{1}{c}{ Kategori } & Ket.Isu \\
\hline Kemudahan dokter untuk ditemui & 3,15 & $\begin{array}{l}\text { Biasa } \\
\text { saja/netral }\end{array}$ & Isu \\
\hline $\begin{array}{l}\text { Perhatian tulus (care) dokter dan perawat } \\
\text { dalam menyelesaikan masalah yang } \\
\text { dialami pasien }\end{array}$ & 3,71 & Puas & Bukan Isu \\
\hline $\begin{array}{l}\text { Kemampuan dokter dan perawat } \\
\text { menangani komplain }\end{array}$ & 3,62 & Puas & Bukan Isu \\
\hline Nilai Rata-Rata Komposit Keseluruhan & 3,49 & & \\
\hline
\end{tabular}


Berdasarkan Tabel 4. diketahui bahwa terdapat 2 unsur termasuk dalam kategori puas dan 1 unsur termasuk dalam kategori biasa saja/netral. Unsur dengan kategori biasa saja/netral memiliki nilai mean komposit di bawah nilai rata-rata komposit keseluruhan sehingga dapat menjadi isu. Isu dalam unsur-unsur dimensi pemecahan masalah, yaitu kemudahan dokter untuk ditemui.

\section{Dimensi Kebijakan}

Dimensi kebijakan berkaitan
dengan unsur kualitas jasa yang dipengaruhi langsung oleh kebijakan rumah sakit. Kebijakan yang terdapat di sebuah rumah sakit akan mencerminkan tingkat responsif terhadap kebutuhan pasien atau tidak. Dimensi kebijakan meliputi ketepatan jam berkunjung, prosedur administrasi yang jelas, serta ketersediaan ruang tunggu yang nyaman.

Berdasarkan Tabel 5. dapat diketahui bahwa terdapat tiga unsur termasuk kategori puas dan dua unsur termasuk dalam kategori biasa saja/netral. Unsur dengan kategori biasa saja/netral memiliki nilai mean komposit di bawah nilai rata-rata komposit keseluruhan sehingga dapat menjadi isu. Isu dalam unsur-unsur dimensi kebijakan, yaitu kejelasan prosedur administrasi bagi pasien serta ketersediaan ruang tunggu yang nyaman.

\section{PEMBAHASAN}

Pelayanan rawat inap adalah suatu pelayanan utama yang terdapat di rumah sakit dan merupakan tempat interaksi antara pasien dan tenaga kesehatan rumah sakit yang berlangsung dalam waktu lama. Menurut Muninjaya (2004) perawatan rawat inap merupakan perawatan yang diberikan rumah sakit kepada pasien untuk menempati tempat perawat karena keperluan observasi, diagnosis, terapi, rehabilitasi medis, serta untuk mendapatkan pelayanan medis lainnya. Pelayanan rawat inap melibatkan hubungan yang sensitif antara pasien, dokter, dan perawat sehingga menyangkut kepuasan, mutu pelayanan, dan citra rumah sakit. Menurut Supriyanto dan Wulandari (2011) mutu merupakan gambaran menyeluruh dari kemampuan suatu barang atau jasa dalam memuaskan kebutuhan pelanggan baik berupa kebutuhan yang dinyatakan maupun kebutuhan yang tersirat. Mutu tidak lepas dari kualitas suatu barang maupun jasa yang mengandung banyak makna seperti bebas dari segala kerusakan atau kecacatan, kesesuaian produk dalam hal penggunaan, persyaratan, atau tuntutan, melakukan segala sesuatu dengan benar sejak awal, pemenuhan kebutuhan pelanggan sejak awal dengan tepat, serta menumbuhkan kepuasan pelanggan.

Tabel 5. Kepuasan Pasien terhadap Unsur Dimensi Kebijakan di Instalasi Rawat Inap RSU Haji Surabaya Tahun 2017

\begin{tabular}{lrrr}
\hline \multicolumn{1}{c}{ Unsur } & Mean Komposit & Kategori & Ket.Isu \\
\hline $\begin{array}{l}\text { Keterjangkauan tarif pelayanan rawat } \\
\text { inap }\end{array}$ & 4,12 & Puas & Bukan Isu \\
\hline $\begin{array}{l}\text { Ketepatan waktu masuk dan waktu } \\
\text { keluar pasien }\end{array}$ & 3,82 & Puas & Bukan Isu \\
\hline $\begin{array}{l}\text { Ketepatan jam berkunjung bagi kerabat } \\
\text { pasien }\end{array}$ & 3,92 & Puas & Bukan Isu \\
\hline $\begin{array}{l}\text { Kejelasan prosedur administrasi bagi } \\
\text { pasien }\end{array}$ & 3,32 & $\begin{array}{l}\text { Biasa } \\
\text { saja/netral }\end{array}$ & Isu \\
\hline $\begin{array}{l}\text { Ketersediaan ruang tunggu yang nyaman } \\
\text { Nilai Rata-Rata Komposit Keseluruhan }\end{array}$ & 3,25 & $\begin{array}{l}\text { Biasa } \\
\text { saja/netral }\end{array}$ & Isu \\
\hline
\end{tabular}


Mutu pelayanan kesehatan merupakan suatu ukuran atau tingkat kesempurnaan penampilan pelayanan kesehatan yang digunakan untuk mengukur peningkatan mutu dalam memenuhi kebutuhan dan harapan pasien untuk mencapai mutu layanan yang optimal. Mutu pelayanan rumah sakit merupakan ukuran kesempurnaan pelayanan rumah sakit dalam pemenuhan kebutuhan masyarakat konsumen akan pelayanan kesehatan yang sesuai standar profesi, standar pelayanan profesi, dan standar pelayanan dengan menggunakan potensi sumber daya yang tersedia di rumah sakit secara wajar, efisien, dan efektif serta memberikan pelayanan dengan aman sehingga dapat memuaskan sesuai norma, etika, hukum, dan sosio budaya dengan memperhatikan keterbatasan dan kemampuan pemerintah serta masyarakat konsumen. Dimensi mutu di bidang kesehatan dapat mencakup beberapa aspek, antara lain: kompetensi hubungan interpersonal, keamanan dan keselamatan pelanggan, efektivitas dan efisiensi pengelolaan, memberikan pelayanan dengan wajar dan efektif, kontinuitas, serta dalam hal keterjangkauan. Mutu pelayanan kesehatan umumnya berkaitan dengan pelayanan kesehatan yang diberikan oleh suatu institusi atau fasilitas kesehatan seperti rumah sakit kepada perorangan atau pasien.

Menurut Kotler (1997) kepuasan pelanggan merupakan tingkat perasaan seseorang setelah membandingkan kinerja yang diberikan dibanding harapan pelanggan. Terdapat beberapa faktor yang mempengaruhi kepuasan pengguna jasa pelayanan kesehatan antara lain: aspek komunikasi antara petugas kesehatan dengan pasien mengenai pemahanan pasien terhadap jenis pelayanan kesehatan yang akan diterima, sikap empati (peduli) yang ditunjukkan oleh petugas kesehatan yang akan menyentuh emosi pasien, kesesuaian biaya pelayanan dengan jenis perawatan dan teknologi kedokteran yang ditawarkan oleh rumah sakit, penampilan fisik (kerapian) petugas serta kondisi kebersihan dan kenyamanan ruangan, jaminan keamanan yang diberikan oleh petugas kesehatan seperti ketepatan jadwal pemeriksaan dan kunjungan dokter, keandalan dan keterampilan petugas kesehatan dalam memberikan pelayanan, serta kecepatan dan ketanggapan petugas dalam menangani keluhan pasien dan keluarga pasien (Muninjaya 2004). Menurut Supriyanto dan Wulandari (2011) salah satu alat yang digunakan untuk mengukur kepuasan pelanggan adalah survey kepuasan konsumen atau pelanggan. Kebanyakan pelanggan yang merasa tidak puas akan mengurangi kunjungan atau berpindah rumah sakit lain. Dalam melakukan survey kepuasan, sebaiknya juga ditanyakan mengenai kebutuhan dan harapan pasien terhadap pelayanan rumah sakit sehingga dapat digunakan untuk memperbaiki mutu pelayanan.

Dabholkar, et al (1996) mengkritik bahwa model Servqual tidak mampu menjelaskan secara akurat persepsi pelanggan terhadap kualitas jasa layanan yang diberikan. Dabholkar juga mengembangkan kualitas jasa dievaluasi meliputi 5 faktor utama, yaitu dimensi fisik (physical aspect), reliabilitas (reliability), interaksi personal (personal interaction), pemecahan masalah (problem solving), serta kebijakan (policy). Setiap dimensi mengandung beberapa unsur yang menjadi penilaian bagi pasien terhadap pelayanan yang diterima selama berada di ruang rawat inap.

\section{Dimensi Fisik}

Dimensi fisik meliputi penampilan fisik dan kenyamanan yang ditawarkan pemberi layanan kepada pelanggan. Hasil dari setiap produk pelayanan yang diberikan dan telah diterima oleh pasien sesuai dengan ketentuan yang ditetapkan.

Kepuasan pasien terhadap unsurunsur dalam dimensi fisik adalah tanggapan atau tingkat perasaan pasien terhadap unsur-unsur pelayanan yang 
diberikan selama dan setelah mendapatkan pelayanan kesehatan. Dalam penelitian ini dilakukan penilaian kepuasan pasien terhadap enam unsur dalam dimensi fisik. Unsur pertama yaitu kelengkapan peralatan medis, merupakan rumah sakit yang mempunyai peralatan lengkap dan canggih sehingga pasien dapat memperoleh pelayanan dengan maksimal. Unsur kedua yaitu penataan layout interior dan eksterior, merupakan kondisi dan penataan ruangan rawat inap baik interior maupun eksterior yang menarik secara visual sehingga pasien tidak bosan selama menempati ruangan. Unsur ketiga yaitu kerapian penempatan dan penampilan dokter, merupakan kondisi keteraturan penempatan plastik tempat obat serta peralatan medis dan non medis lainnya juga penampilan dokter saat memberikan pelayanan. Unsur keempat yaitu kebersihan ruang tunggu dan kamar kecil, merupakan kondisi fasilitas ruang tunggu dan kamar kecil yang memadai serta harus selalu bersih akibat banyaknya pasien dan pengunjung pasien. Unsur kelima yaitu ketersediaan penunjuk nama ruang, merupakan keberadaan penunjuk nama ruang di setiap lokasi yang strategis untuk memudahkan pasien dan kerabat pasien dalam mencari ruangan. Unsur keenam yaitu kenyamanan ruang rawat inap, merupakan kondisi penerangan yang mencukupi, kesejukan di dalam ruangan, serta ketenangan yang dirasakan pasien saat jam istirahat.

Berdasarkan hasil penelitian Tabel 1. terdapat tiga unsur dengan kepuasan rendah yang berarti pasien merasa tidak puas terhadap pelayanan yang tersedia sehingga menjadi isu mutu layanan. Unsur pertama yaitu penataan layout interior dan eksterior. Pasien merasa tidak puas terhadap unsur tersebut karena tatanan ruang rawat inap kurang menarik secara visual dan terkesan monoton sehingga pasien merasa cepat bosan. Menurut Tjiptono (2006) aspek fisik mencakup penampilan fisik dan kenyamanan yang ditawarkan kepada pelanggan berkaitan dengan layout fasilitas. Kemenarikan ruangan akan membuat pasien merasa lebih nyaman dan membantu kondisi psikis pasien agar cepat sembuh. Rekomendasi yang dapat diberikan adalah pihak rumah sakit mengubah warna ruangan yang semula cream dan putih menjadi hijau agar terkesan menyejukkan. Unsur kedua yaitu kebersihan ruang tunggu dan kamar kecil. Pasien merasa tidak puas terhadap unsur tersebut karena terdapat ruang rawat inap dengan jumlah kamar kecil yang tidak sebanding dengan jumlah pasien yang sedang dirawat sehingga perlu mengantri dan kamar kecil menjadi cepat kotor. Menurut Pohan (2007) terdapat beberapa aspek yang mungkin dapat mempengaruhi kepuasan pasien rawat inap rumah sakit yaitu instalasi rawat inap tertata rapi, bersih, dan nyaman. Kebersihan juga dapat mencegah penularan penyakit lain yang dapat memperparah kondisi pasien.

Rekomendasi yang dapat diberikan adalah mengusulkan penempatan untuk menambah jumlah kamar kecil serta pemantauan kinerja petugas kebersihan oleh pihak rumah sakit. Unsur ketiga yaitu kenyamanan ruangan dalam hal penerangan, kesejukan, dan ketenangan. Penerangan di ruang rawat inap saat siang hari sudah cukup baik karena tersedia cukup jendela untuk mendapatkan sinar dari luar. Pasien merasa tidak puas terhadap unsur tersebut karena kurangnya kesejukan di dalam ruangan akibat keterbatasan jumlah kipas angin yang harus berbagi dan menyesuaikan kecepatan kipas angin dengan kesepakatan pasien lain. Untuk unsur ketenangan, pasien merasa masih terdapat banyak anak kecil yang berkeliaran serta pengunjung berlebihan sehingga mengganggu jam istirahat pasien (Piranti, 2017). Rekomendasi yang dapat diberikan adalah pengaturan jumlah pengunjung oleh pihak rumah sakit agar ruangan tidak terasa pengap dan tidak mengganggu jam istirahat pasien. 


\section{Dimensi Reliabilitas}

Dimensi reliabilitas merupakan
kemampuan memberikan $\begin{array}{r}\text { pelayanan } \\ \text { dengan cepat dan tepat tanpa membuat }\end{array}$
kesalahan sejak awal. Pelayanan yang
cepat dapat memberikan informasi
mengenai layanan yang akan diberikan.
Reliabilitas dipilah menjadi dua sub
dimensi yaitu keeping promise dan doing it
right.

Kepuasan pasien terhadap unsurunsur dimensi reliabilitas adalah tanggapan atau tingkat perasaan pasien terhadap unsur-unsur pelayanan yang diberikan selama dan setelah mendapatkan pelayanan kesehatan. Dalam penelitian ini dilakukan penilaian kepuasan pasien terhadap lima unsur dalam dimensi reliabilitas. Unsur pertama yaitu ketepatan visite dokter, merupakan ketepatan kunjungan dokter yang memeriksa pasien tepat waktu. Unsur kedua yaitu ketepatan jam makan pasien, merupakan ketepatan datangnya makanan pasien setiap pagi, siang, dan malam serta pemberian makanan tambahan lainnya. Unsur ketiga yaitu kecepatan dan ketepatan pelayanan medis, merupakan pemberian pelayanan yang dilakukan secara cepat dan tepat sejak awal. Unsur keempat yaitu kemudahan mendapatkan obat, merupakan kemudahan pasien dan keluarga pasien dalam mencari obat yang dibutuhkan dengan mengetahui lokasi apotek yang tersedia di rumah sakit. Unsur kelima yaitu ketepatan waktu pemeriksaan laboratorium, merupakan pelayanan pemeriksaan laboratorium sesuai dengan yang dibutuhkan serta ketepatan waktu keluarnya hasil pemeriksaan laboratorium.

Berdasarkan hasil penelitian Tabel

2. terdapat dua unsur dengan kepuasan rendah yang berarti pasien merasa tidak puas terhadap pelayanan yang tersedia sehingga menjadi isu mutu layanan. Unsur pertama yaitu kecepatan dan ketepatan pelayanan yang diberikan sejak awal. Pasien merasa tidak puas terhadap unsur tersebut karena masih terdapat perbedaan perlakuan yang diberikan antara pasien umum dengan pasien BPJS dalam kecepatan mendapatkan pelayanan khususnya mendapatkan tempat tidur. Menurut Supriyanto dan Wulandari (2011) salah satu penilaian konsumen terhadap produk adalah keinginan untuk dapat menyediakan pelayanan yang dibutuhkan dengan segera. Salah satu indikator yang diukur adalah kecepatan pelayanan yang diberikan saat pasien membutuhkan dengan waktu tunggu yang pendek. Rekomendasi yang dapat diberikan adalah sebaiknya pihak rumah sakit melakukan evaluasi terhadap petugas di tempat untuk memperlakukan sama terhadap semua pasien sesuai prosedur. Unsur kedua yaitu ketepatan waktu pemeriksaan laboratorium. Pasien merasa tidak puas terhadap unsur tersebut karena lamanya waktu menunggu hasil pemeriksaan laboratorium. Rekomendasi yang dapat diberikan adalah sebaiknya pihak rumah sakit melakukan evaluasi terhadap petugas laboratorium untuk segera melakukan tindakan setiap terdapat permintaan pemeriksaan laboratorium.

\section{Dimensi Interaksi Personal}

Dimensi interaksi personal menekankan pada kemampuan pemberi layanan dalam menumbuhkan kepercayaan kepada pasien dan sikap sopan atau suka membantu. Dimensi interaksi personal merefleksikan cara petugas kesehatan memperlakukan pasien secara langsung sehingga pasien merasa aman dalam memanfaatkan pelayanan di rumah sakit.

Kepuasan pasien terhadap unsurunsur dalam dimensi interaksi personal adalah tanggapan atau tingkat perasaan pasien terhadap unsur-unsur pelayanan yang diberikan selama dan setelah mendapatkan pelayanan kesehatan. Penelitian ini dilakukan penilaian kepuasan pasien terhadap sembilan unsur dalam dimensi interaksi personal. Unsur pertama yaitu pengetahuan dokter dan perawat, merupakan sikap dokter dan perawat dalam menjawab segala pertanyaan yang diajukan pasien maupun keluarga pasien mengenai penjelasan perawatan medis 
yang akan diberikan beserta akibatnya bagi pasien. Unsur kedua yaitu sikap dokter selama pelayanan, merupakan sikap dokter dalam memberikan pelayanan dapat menumbuhkan kepercayaan pasien dan membuat pasien merasa aman. Unsur ketiga yaitu empati perawat, merupakan sikap perawat dalam mendengarkan keluhan pasien dengan sabar dan turut merasakan hal yang sama dirasakan oleh pasien. Unsur keempat yaitu responsif dokter dan perawat, merupakan ketanggapan dokter dan perawat dalam mengatasi masalah pasien dan memberikan solusi terbaik. Unsur kelima yaitu kejelasan informasi waktu pemeriksaan, merupakan dokter memberitahu pasien kapan persisnya pelayanan lebih lanjut akan diberikan. Unsur keenam yaitu keramahan perawat, merupakan sikap perawat dalam memenuhi permintaan pasien dengan selalu tersenyum. Unsur ketujuh yaitu perhatian dokter dan perawat, merupakan ketulusan dokter dan perawat kepada pasien selama menerima perawatan. Unsur kedelapan yaitu respek perawat, merupakan kesopanan perawat dalam memperhatikan setiap detail kondisi pasien. Unsur kesembilan yaitu kesopanan dokter dan perawat dalam konsultasi, merupakan kesopanan dokter dan perawat dalam menerima konsultasi melalui telepon jika sedang tidak berada di rumah sakit.

Tabel 3. menunjukkan terdapat tiga unsur dengan kepuasan rendah yang berarti pasien merasa tidak puas terhadap pelayanan yang tersedia sehingga menjadi isu mutu layanan. Unsur pertama yaitu empati perawat terhadap keluhan pasien. Pasien merasa tidak puas terhadap unsur tersebut karena masih terdapat perawat yang kurang senyum dan terkesan cuek jika pasien mengajukan keluhan sehingga pasien menjadi tidak nyaman. Dalam memberikan pelayanan seharusnya petugas harus dapat memperlakukan pasien dengan mau mendengarkan keluhan pasien dengan sabar dan menunjukkan sikap peduli. Menurut Pohan (2007) salah satu aspek yang mungkin mempengaruhi kepuasan pasien terhadap pelayanan kesehatan adalah keramahan petugas dalam memberikan layanan. Unsur kedua yaitu keramahan perawat dalam memenuhi permintaan pasien. Salah satu faktor yang mempengaruhi kualitas jasa pelayanan adalah keramahan dalam memberikan pelayanan terutama bagi mereka yang melakukan interaksi dan kontak langsung dengan pelanggan (Gaspersz, 2002). Citra pelayanan dari pelayanan jasa sangat ditentukan oleh orang yang berada di garis terdepan dalam melayani langsung pelanggan. Menurut Supriyanto dan Ernawaty (2010) petugas pemberi layanan harus senantiasa murah senyum dalam memenuhi kebutuhan dan harapan pasien. Unsur ketiga yaitu respek (kesopanan) perawat dalam memperhatikan pasien. Kesopanan perawat dalam memberikan pelayanan merupakan sikap yang harus selalu dilakukan agar pasien merasa aman dan nyaman dalam menyampaikan keluhan secara spesifik. Salah satu aspek yang mungkin mempengaruhi kepuasan pasien adalah kesopanan dalam melayani pasien. Rekomendasi yang dapat diberikan untuk ketiga unsur tersebut adalah sebaiknya rumah sakit mengadakan pelatihan untuk melakukan evaluasi terhadap interpersonal communication skill bagi petugas kesehatan serta petugas yang memberikan layanan diharapkan mampu berkomunikasi dengan pasien menggunakan bahasa daerah setempat.

\section{Dimensi Pemecahan Masalah}

Dimensi pemecahan masalah mencakup kepekaan dan ketanggapan pemberi layanan dalam mengatasi komplain dari pasien dan keluarga pasien. Dimensi ini melibatkan interaksi antara pasien dan petugas kesehatan secara spesifik berkaitan dengan tanggapan penanganan masalah.

Kepuasan pasien terhadap unsurunsur dimensi pemecahan masalah adalah tanggapan atau tingkat perasaan pasien terhadap unsur-unsur pelayanan yang 
diberikan selama dan setelah mendapatkan pelayanan kesehatan. Dalam penelitian ini dilakukan penilaian kepuasan pasien terhadap tiga unsur dalam dimensi pemecahan masalah. Unsur pertama yaitu kemudahan dokter untuk ditemui, merupakan keberadaan dokter yang mudah ditemui untuk melakukan konsultasi jika sewaktu-waktu dibutuhkan oleh pasien dan keluarga pasien. Unsur kedua yaitu perhatian tulus (care) dokter dan perawat, dalam menyelesaikan masalah yang dialami pasien selama menerima perawatan. Unsur ketiga yaitu kemampuan dokter dan perawat dalam menangani keluhan pasien secara langsung dan memberikan solusi.

Berdasarkan hasil penelitian Tabel 4. terdapat satu unsur dengan kepuasan rendah yang berarti pasien merasa tidak puas terhadap pelayanan yang tersedia sehingga menjadi isu mutu layanan yaitu unsur kemudahan dokter untuk ditemui. Pasien merasa tidak puas terhadap unsur tersebut karena pasien dapat bertemu dokter hanya pada saat visite dokter saja dengan waktu yang tidak tentu sehingga saat pasien membutuhkan dokter secara tiba-tiba dokter tidak sedang berada di rumah sakit. Menurut Tjiptono (2011) diperlukan meluangkan waktu untuk mendengarkan keluhan pelanggan dan berusaha memahami situasi yang dirasakan oleh pelanggan. Rekomendasi yang dapat diberikan adalah pihak rumah sakit perlu memperbaiki kebijakan jumlah dokter jaga sesuai dengan prosedur serta sebaiknya dokter tetap dapat melayani pasien via telepon atau email saat dokter sedang tidak berada di rumah sakit.

\section{Dimensi Kebijakan}

Dimensi kebijakan mencakup aspek kualitas jasa pelayanan yang secara langsung dapat dipengaruhi oleh kebijakan rumah sakit. Kebijakan suatu rumah sakit dapat mencerminkan tingkat ketanggapan rumah sakit terhadap harapan dan kebutuhan pelanggan.
Kepuasan pasien terhadap unsurunsur dalam dimensi kebijakan adalah tanggapan atau tingkat perasaan pasien terhadap unsur-unsur pelayanan yang diberikan selama dan setelah mendapatkan pelayanan kesehatan. Dalam penelitian ini dilakukan penilaian kepuasan pasien terhadap lima unsur dalam dimensi kebijakan. Unsur pertama yaitu keterjangkauan tarif, merupakan kebijakan rumah sakit dalam menentukan tarif rawat inap yang terjangkau dan sesuai dengan pelayanan yang dibutuhkan. Unsur kedua yaitu ketepatan waktu, merupakan ketepatan waktu masuk pasien saat pertama kali membutuhkan pelayanan serta waktu keluar pasien setelah mendapatkan pelayanan dan sembuh. Unsur ketiga yaitu ketepatan jam berkunjung, merupakan kebijakan rumah sakit mengenai jam berkunjung bagi pengunjung yang terpasang jelas sehingga membatasi jumlah pengunjung dan tidak menganggu waktu istirahat pasien. Unsur keempat yaitu kejelasan prosedur administrasi, merupakan kebijakan rumah sakit dalam menyampaikan prosedur administrasi yang tidak berbelit dan mudah dimengerti sehingga pasien dan keluarga pasien tidak kebingungan dalam melengkapi persyaratan administrasi. Unsur kelima yaitu ketersediaan ruang tunggu, merupakan kebijakan rumah sakit mengenai ketersediaan ruang tunggu yang nyaman agar pengunjung pasien tidak merasa bosan dengan memberikan fasilitas pendukung lainnya seperti televisi.

Berdasarkan hasil penelitian Tabel 5. terdapat dua unsur dengan kepuasan rendah yang berarti pasien merasa tidak puas terhadap pelayanan yang tersedia sehingga menjadi isu mutu layanan. Unsur pertama yaitu kejelasan prosedur adminsitrasi bagi pasien. Sebagian besar pasien rawat inap adalah pasien BPJS sehingga untuk pengurusan administrasi harus melewati beberapa prosedur dan persyaratan tertentu. Pasien merasa kesulitan karena banyaknya berkas yang harus disiapkan serta alur pengurusan yang 
kompleks. Pihak pengelola rumah sakit harus dapat selalu berpikir dan mengambil tindakan untuk memuaskan pelanggan (Arifin dan Prasetya, 2006). Beberapa tuntutan konsumen yang harus dipenuhi antara lain penyediaan tenaga medis dan paramedis yang profesional, prosedur yang tidak berbelit, kecepatan pelayanan, serta menciptakan lingkungan yang aman dan nyaman. Rekomendasi yang dapat diberikan adalah sebaiknya pihak rumah sakit melakukan perbaikan pada kebijakan dalam hal prosedur administrasi agar lebih jelas, tidak berbelit, dan mudah dipahami oleh pasien dan keluarga pasien sehingga proses administrasi dapat berjalan lancar. Unsur kedua yaitu ketersediaan ruang tunggu yang nyaman. Banyaknya pengunjung pasien membuat pasien merasa terganggu dan menjadi tidak puas. Penunggu pasien di rawat inap terkadang lebih dari dua orang selaku keluarga dan/atau kerabat pasien sehingga harus duduk bahkan tidur di lantai menggunakan karpet pribadi. Menurut Gaspersz (2002) atribut yang harus diperhatikan dalam melakukan perbaikan jasa pelayanan antara lain atribut pendukung lainnya seperti kebersihan, adanya ruang tunggu, fasilitas musik, televisi, dan lain sebagainya. Keadaan ruang tunggu yang nyaman akan membuat pengunjung pasien menjadi tidak bosan. Rekomendasi yang dapat diberikan adalah sebaiknya pihak rumah sakit menyediakan tempat khusus tambahan bagi keluarga dan/atau kerabat pasien yang menunggu serta mempertegas kebijakan mengenai jam berkunjung dan memberi teguran kepada keluarga dan/atau kerabat pasien yang berkunjung di luar jam berkunjung yang telah ditetapkan.

\section{SIMPULAN}

Berdasarkan hasil penelitian dan pembahasan dapat diketahui kategori kepuasan tiap unsur dan nilai masingmasing unsur dengan mean komposit lebih dari sama dengan rata-rata komposit keseluruhan berarti puas dan bukan isu, sedangkan unsur dengan mean komposit kurang dari rata-rata komposit keseluruhan berarti pasien tidak puas dan menjadi isu. Masing-masing unsur dalam mutu pelayanan kesehatan berdasarkan Dimensi Mutu Dabholkar dengan kepuasan rendah berarti pasien merasa tidak puas terhadap pelayanan yang tersedia sehingga menjadi isu mutu layanan yang perlu diperbaiki.

$$
\text { Berdasarkan dimensi fisik }
$$

diketahui lima unsur dengan kategori puas dan satu unsur dengan kategori biasa saja/netral, namun terdapat tiga unsur yang menjadi isu mutu layanan antara lain: penataan layout interior dan eksterior, kebersihan ruang tunggu dan kamar kecil, serta kenyamanan dalam hal penerangan, kesejukan, dan ketenangan. Berdasarkan dimensi reliabilitas diketahui semua unsur termasuk kategori puas namun terdapat dua unsur yang menjadi isu mutu layanan antara lain: kecepatan dan ketepatan pelayanan yang diberikan sejak awal serta ketepatan waktu pemeriksaan laboratorium. Berdasarkan dimensi interaksi personal diketahui enam unsur dengan kategori puas dan tiga unsur dengan kategori biasa saja/netral sekaligus menjadi isu mutu layanan antara lain: empati perawat terhadap keluhan pasien, keramahan perawat dalam memenuhi permintaan pasien, serta respek (kesopanan) perawat dalam memperhatikan pasien. Berdasarkan dimensi pemecahan masalah diketahui dua unsur dengan kategori puas dan satu unsur dengan kategori biasa saja/netral sekaligus menjadi isu mutu layanan yaitu kemudahan dokter untuk ditemui. Berdasarkan dimensi kebijakan diketahui tiga unsur dengan kategori puas dan dua unsur dengan kategori biasa saja/netral sekaligus menjadi isu mutu layanan antara lain: kejelasan prosedur administrasi bagi pasien serta ketersediaan ruang tunggu yang nyaman.

Rekomendasi yang dapat diberikan pada dimensi fisik antara lain: pihak rumah sakit mengubah warna ruangan yang semula cream dan putih menjadi hijau agar 
terkesan menyejukkan, mengusulkan penempatan untuk menambah kamar kecil serta pemantauan kinerja petugas kebersihan oleh pihak rumah sakit, serta pengaturan jumlah pengunjung oleh rumah sakit agar ruangan tidak terasa pengap dan tidak menganggu waktu istirahat pasien lain. Rekomendasi pada dimensi reliabilitas antara lain: sebaiknya pihak rumah sakit melakukan evaluasi terhadap petugas yang memberikan pelayanan untuk memperlakukan sama terhadap semua pasien sesuai prosedur serta melakukan evaluasi terhadap petugas laboratorium untuk segera melakukan tindakan setiap terdapat permintaan pemeriksaan laboratorium. Rekomendasi pada dimensi interaksi personal antara lain: sebaiknya pihak rumah sakit mengadakan pelatihan untuk melakukan evaluasi terhadap interpersonal communication skill serta petugas diharapkan mampu menggunaakan bahasa daerah setempat. Rekomendasi pada dimensi pemecahan masalah antara lain: pihak rumah sakit perlu memperbaiki kebijakan jumlah dokter jaga sesuai dengan prosedur serta sebaiknya dokter tetap dapat melayani konsultasi pasien melalui telepon atau email saat dokter sedang tidak berada di rumah sakit dan sewaktu-waktu dibutuhkan. Rekomendasi pada dimensi kebijakan antara lain: sebaiknya pihak rumah sakit melakukan perbaikan terhadap kebijakan dalam hal prosedur administrasi agar lebih jelas, tidak berbelit, dan mudah dipahami agar proses administrasi berjalan lancar serta sebaiknya rumah sakit menyediakan tempat khusus tambahan bagi keluarga dan/atau kerabat pasien yang menunggu sekaligus mempertegas kebijakan mengenai jam berkunjung dan memberi teguran kepada keluarga dan/atau kerabat pasien yang berkunjung di luar jam berkunjung yang telah ditetapkan.

\section{DAFTAR PUSTAKA}

Arifin., Prasetya. 2006. Manajemen Rumah Sakit Modern Berbasis Komputer:
Mencakup Aspek Pemasaran dan Manajemen Keuangan. Jakarta: PT. Elex Media Komputindo Kelompok Gramedia, Anggota IKAPI.

Dabholkar, P.A., Thorpe, D.I. \& Rentz, J.O. 1996. A Measure of Service Quality for Retail Stories: Scale Development and Validation. Journal of The Academy of Marketing Science 24 (1): 3-16. Berlin: Springer-Verlag. [https:// https://doi.org/10.1177/009207039 602400101]

Gaspersz, V. 2002.Manajemen Kualitas dalam Industri Jasa Manajemen Bisnis Total. Jakarta: Gramedia Pustaka Utara.

Gaspersz, V. 2005.Total Quality Management. Jakarta: Gramedia Pustaka Utama.

Keputusan Menteri Kesehatan Nomor 129 Tahun 2008 tentang Standar Pelayanan Minimal Rumah Sakit. Jakarta.

Kotler, Philip. 1997. Manajemen Pemasaran, Jilid 2. New Jersey: Prentice Hall.

Muninjaya, A.A. 2004. Manajemen Kesehatan. Jakarta: Penerbit Buku Kedokteran EGC.

Peraturan Menteri Kesehatan Republik Indonesia Nomor 340 Tahun 2010 tentang Klasifikasi Rumah Sakit. Jakarta.

Piranti, K., 2017. Analisis Mutu Pelayanan di Instalasi Rawat Inap Rumah Sakit Umum Haji Surabaya berdasarkan Dimensi Mutu Dabholkar. Skripsi. Surabaya: Universitas Airlangga.

Pohan, Imbalo. 2007. Jaminan Mutu Layanan Kesehatan: Dasar-Dasar Pengertian dan Penerapan. Jakarta: Penerbit Buku Kedokteran EGC.

Rumah Sakit Umum Haji Surabaya. 2014. LAKIP Rumah Sakit Umum Haji Surabaya Tahun 2014. Surabaya. 
Rumah Sakit Umum Haji Surabaya. 2015. LKj RSU Haji Surabaya Tahun 2015. Surabaya.

Rumah Sakit Umum Haji Surabaya. 2015. Review RENSTRA RSU Haji Surabaya Tahun 2015-2019. Surabaya.

Rumah Sakit Umum Haji Surabaya. 2016. Laporan Kinerja BLUD RSU Haji Surabaya Tahun 2016: Laporan Akhir IKM RSU Haji Surabaya. Surabaya.

Supranto, J. 2001. Pengukuran Tingkat Kepuasan Pelanggan. PT. Andi Mahasatya: Jakarta.

Supriyanto, S., Ernawaty. 2010. Pemasaran Industri Jasa
Kesehatan. Yogyakarta: Penerbit Andi.

Supriyanto, S., Wulandari, R. D. 2011.Manajemen Mutu Pelayanan Kesehatan. Surabaya: Health Advocacy.

Tjiptono, Fandy. $1997 . \quad$ Strategi Pemasaran, Edisi Kedua. Yogyakarta: Penerbit Andi.

Tjiptono, Fandy. 2006. Pemasaran Jasa, Edisi Pertama, Cetakan Kedua. Malang: Bayumedia Publishing.

Undang-Undang Republik Indonesia Nomor 44 Tahun 2009 tentang Rumah Sakit. Jakarta. 